\title{
Interest group representation on government committees in Kenya
}

\author{
David Irwin ${ }^{1}$ (D) Mercy Kyande ${ }^{2}$
}

Accepted: 12 December 2021 / Published online: 9 February 2022

(c) The Author(s), under exclusive licence to Springer Nature Limited 2022

\begin{abstract}
Business associations engage in dialogue with policy makers-and sometimes succeed in influencing policy outcomes. One strategy-largely overlooked by researchers-involves seeking appointment to government boards and committees. This is an important omission since many committees review, draft and implement policies and regulations. Securing representation on government committees could thus lead to considerable influence but little is known about the extent to which interest groups seek such appointments. And very little is known about dialogue in developing countries, especially those that seek a consensual rather than an adversarial approach to policy formulation. This research, based on desk research of government committee membership and interviews with business associations, thus addresses two gaps. It has been undertaken in a developing country, Kenya, since there is a relatively small number of interest groups compared to other countries of a similar population. This research focuses on the efforts of interest groups, and business groups in particular, to place nominees on government committees. This article highlights the level of regulatory activity in Kenya effectively delegated to government boards and committees and demonstrates the apparent success of business associations in securing participation in a majority of the committees with a regulatory function. It argues, however, that interest groups could be more professional and more strategic when they are represented on government committees.
\end{abstract}

Keywords Dialogue $\cdot$ Advocacy $\cdot$ Representation $\cdot$ Public committees $\cdot$ Kenya Africa

David Irwin

david@irwin.org

1 Department of Politics, Newcastle University, Newcastle upon Tyne NE1 7RU, United Kingdom

2 Nairobi, Kenya 


\section{Introduction}

Much interest group activity, at least for those adopting an insider approach, comprises meetings and other communications with policy makers in an attempt to influence their views and actions (Maloney et al. 1994). One technique, often overlooked by both interest groups and researchers but potentially effective, is to seek membership of government appointed committees, boards, task forces and technical committees, especially those concerned with reviewing or formulating public policy, defined by Mintrom as "the choices that governments make on behalf of citizens [...] codified in the rules, plans, principles and strategies that guide government action" (2012: 1). The European Union in particular, believing itself to be short of resources, seeks to engage people with knowledge and expertise by appointing them to policy advisory groups and the "involvement of experts in policy making is widely viewed as enhancing the effectiveness of public policies" (Metz 2014: 263).

Securing positions on government committees may be perceived by outsiders as opaque and lacking transparency, as corporatist rather than pluralist, as narrowing debate rather than broadening but it also assists policy makers by bringing in a range of voices and expertise that might be expected to enhance the legitimacy and quality of policy making (Dür and Mateo 2012) and fill a gap that would otherwise exist in allowing for the possibility of direct influence over public policy (Jordan and Maloney 2007). Appointments, however, are inevitably political (Brown 2008) and thus not necessarily balanced.

Scholars have examined the work and impact of the European Commission's expert groups though not in great detail (Chalmers 2014). Christiansen et al. (2010) have assessed the extent to which interest groups are involved in government committees in Scandinavia but more to measure the strength of corporatism than to assess the effectiveness of the groups represented. More generally, it appears that the ability of interest groups to secure membership of government task forces, government committees and expert policy groups and their effectiveness in influencing public policy is largely overlooked by researchers. Participation does not directly result, in the short term, in regulatory or policy reform and does not, in itself, constitute policy reform, but it does mean that representatives of business associations and other interest groups are in a much better position to engage in dialogue with policy makers and to influence the agency, committee, board or expert group (hereinafter, government committees).

This research has been undertaken in Kenya. Firstly, the approaches, activities and successes of interest groups in developing countries have been under-researched in the academic literature leading Mahoney (2008) to wonder whether interest groups in more communal societies behave in a similar way to those in individualist consolidated democracies-especially relevant to the deliberation of government committees.

Secondly, the impression is that there is more emphasis in Africa on dialogue-which the World Bank (2005) defines as a structured interaction between public and private sectors to analyse problems and agree on reforms-than on lobbying 
(which business membership organisations in Africa tend to use to describe faceto-face persuasion). An emphasis on dialogue reflects the culture which, in Africa, tends to be consensual and policy formulation more collaborative (Wiredu 2015) and the political context which, in Africa tends to be more neopatrimonial or clientelist (Kuada 2015) or authoritarian (Kimenyi \& Datta 2011), although it could also, at least in part, be explained by the much smaller number of interest groups making it easier for them to secure attention. Moreover, it is easier to have meaningful dialogue if the groups are small.

Thirdly, compared to developed countries, there are many fewer interest groups and many fewer government committees making it much easier to observe the relationships.

Lastly, this subject is very topical. The Kenyan newspaper, The Citizen (Walter 2021) reported in May that the High Court of Kenya had declared as opaque and thus unconstitutional the Government's appointment of 128 heads of parastatals. Watta (2021), writing about Kenyan boards in general, observes that "appointment of directors is left to the whims of appointing authorities, making this important decision arbitrary, random and subject to possible abuse where there is no oversight or accountability". He goes on to note that "in some instances, appointment to boards is regarded as political reward, meaning that critical public and private institutions are saddled with directors who neither understand the institutions they oversee nor have the necessary skills and qualifications to hold those positions". That may explain why the High Court argued in their ruling that the people of Kenya desired that appointments to parastatal boards "must be competitive, fair and transparent" (Walter 2021).

This initial research is quite wide ranging but focuses on identifying the level of membership of representatives of interest groups on government committees. The research suggests that a few have been very successful but there are several issues that need to be addressed if interest groups are to be able to utilise membership of government committees in a transparent and accountable way. Moreover, there is a need for further in-depth research on the effectiveness of interest groups representatives.

This paper commences with a review of interest groups and involvement in government committees, with a focus on Kenya. This section is followed by a description of the approach to the research, then the results and analysis. The paper concludes with a discussion and suggestions for further research.

\section{Interest groups and government committees}

Interest groups in general, and business associations in particular, lobby government in an effort to improve the business enabling environment, that is, to make it easier to do business. To be effective, they need access and seek that through engaging in bilateral and multilateral dialogue as well as submitting written proposals, mobilising grass roots support, etc. Moreover, consultation with interest groups is an important part of the democratic process and interest groups are important sources of information, knowledge and expertise (Fink-Hafner and Krašovec 2005: 404). In 
many countries, Kenya included, policy makers and interest groups interact through formal consultation arrangements including, on occasion, participation by representatives of interest groups on government committees, advisory bodies and working groups (Fraussen et al. 2015). Such participation allows interest groups more easily to share concerns, knowledge and expertise with government policy makers. Indeed, the Organisation for Economic Cooperation and Development, in describing a broad range of advocacy techniques, specifically includes "the influence of special interests through participation in established institutional arrangements such as government advisory and expert groups or parliamentary inter-groups" (OECD 2021: 18). Transparency International (TI) also recognises committee work as a form of advocacy (TI 2015) and calls for legal obligations to ensure balance compositions to represent diverse interests and for members of such groups to disclose their interests and affiliations. As long ago as 2009, the Council of Europe (undated) developed a code of good practice to govern civil participation in policy decision-making, recognising that there is a spectrum of interest group participation ranging simply from informing them through consultation and dialogue to collaboration or partnership. They perceive this level to include participation in committees, co-drafting of regulations, joint decision making and partnerships for implementation.

In consolidated democracies, we find that there is a high level of participation on government committees by business associations and other interest groups. The EU is one of the few governmental organisations to have a register of expert groups (and has 729 at the time of writing - see iga.fyi/eureg1) including a complete list of members (of which there are more than 37,000) and their declaration of interests. Moreover, individuals appointed to represent an interest or organisations such as associations can only be appointed if they are already listed in the Transparency Register (iga.fyi/eutr). Although appointment to EU expert groups is decided by the European Commission (EC) and, moreover, the EC is not obliged to follow any of the recommendations of the groups, interest groups overall are clearly offered a high level of access. The USA makes even more use of advisory committees-with an estimated 65,000 members on 1,000 advisory committees (McGrath 2013)-leading Barack Obama, following his election as President of the United States, to ban registered lobbyists from sitting on government boards and advisory committees. This may, however, have disadvantaged both the smaller business associations and the committees. McGrath (2013), drawing a distinction between public interest lobbyists, including business associations, and private corporate lobbyists, more likely to be lobbying for vested interests, noted that the US Trade Representative protested on the basis that business associations were valuable members of committees because of the expertise they brought with them.

Christiansen et al (2010) note that the degree of participation of interest groups in government committees provides an indicator of the extent to which they are integrated into the policy making process though Binderkrantz and Christiansen noted that of 273 committees in Denmark with interest group representation in 2010, just three were concerned with drafting policies (2015: 1030). However, participation in government committees does offer interest groups a privileged opportunity (Christiansen et al. 2010). Membership on government committees not only gives interest groups extra opportunities to be heard but also gives them access to information and 
networks not available to other groups (Binderkrantz and Christiansen 2015) though there is perhaps a broader question-about the role and effectiveness of the government committees - and thus whether participation is an effective means of policy advocacy.

It is easy to understand why business membership organisations (BMO) might want nominees on boards and committees. Firstly, it gives them advance warning of possible reforms to regulation or legislation. And, secondly, it gives them an opportunity to influence the topics on to the public policy agenda. But governments also like to have a wide representation on boards, committees and task forces as it gives them easy access to research evidence, opinion and multiple points of view (Dür \& Mateo 2012). Involving a representative cross-section of stakeholders makes it less likely that they will fail to see the potential consequences of their decisions.

Rasmussen \& Gross (2015), in line with much academic thinking, see interest groups access as a process of resource exchange: policy makers seek expertise and legitimacy by giving groups representation on advisory committees and interest groups provide these goods in return for a modicum of policy influence. Thus, there seem to be several reasons to include the representatives of interest groups on government committees. Firstly, it brings in people with knowledge and experience; secondly, it provides an easy route to secure additional evidence and opinion; thirdly, it brings them into the policy group in a formal way leading to the fourth reason, conferring legitimacy on the policy outcomes.

Christiansen et al. take a corporatist view in which privileged interest organisations participate in both policy formulation and policy implementation (2010: 26). They suggest that corporatism enables governments "to secure the inclusion and backing of important organised interests that otherwise could thwart policy implementation" (2010: 35) and, indeed, Kenya sees many instances of business associations going to court specifically to obstruct and delay implementation of policy and regulation. They further suggest that, as the number of public committees grows and as interest groups are co-opted into the policy process, the key actors, that is interest group representatives and public officials, get to know and trust each other, they are more likely to continue with those relationships (2010:29).

TI (2015) recognises and supports lobbying as a crucial element of the democratic process but stresses the importance of governments imposing regulations to govern the process of lobbying and, indeed, promotes the need for lobbying registers aiming to ensure a level playing field for different interests with all equally able to participate and to avoid conflicts of interest. They call for interest groups and the wider public to "enjoy open and fair access to public decision-making, allowing for a diversity of input, better policies and ultimately more representative and trusted democracy" (2015: 10). That is why, for expert groups, they call for balanced composition and full disclosure of interests. Arguably, the most transparency is achieved through the creation of national and public registers of members of all government committees, boards and task forces and, where appropriate, the interests that they represent.

In many respects, Kenya is no different to other countries in that there are many business associations (though proportionately many fewer than in developed countries) with a determination to influence public policy. They thus employ all the 
techniques that might be utilised by an interest group in a developed country. There are around 700 business interest groups in Kenya, with around 400 at the national level and a further 300 at the county level (BAF 2020). Most struggle to engage effectively in dialogue and advocacy with perhaps around 20 to 30 that can realistically expect to influence policy makers, many of which have achieved considerable success (Irwin and Githinji 2016). Much of the work of business membership organisations focuses on engaging with policy makers to persuade them to do something or not do something. This involves gathering evidence, preparing policy positions and then discussing and debating with policy makers and other stakeholders in an effort to secure the desired reforms. Business membership organisations thus seek to place representatives on task forces and technical committees reviewing existing legislation or considering proposals for new legislation and regulation. They subsequently seek representation on task forces mandated to implement new regulations. Inevitably, they also seek representation on boards and committees of a wide range of parastatal organisations. Allied with the importance of groups to African society (Chazan et al. 1999) and a desire to seek compromise, one might expect better policy to emerge from the arguments of groups with different positions.

A parastatal organisation, at least in Kenya, is an organisation established by the state, often as a state corporation or company, to undertake activities on behalf of the state but outside of direct Ministerial control. Kenya has more than 200 parastatals. These can be classified into three types: those that are primarily regulatory, such as the Export Processing Zones Authority, the Tourism Regulatory Authority, the National Construction Authority and the National Employment Authority; those that are primarily managerial or governing such as KenInvest, the Kenya Institute for Public Policy Research and Analysis (though the research institutes can and do influence policy and regulation) and state owned enterprises, such as KenGen; and those that are managerial but with a wider, often promotional, function such as the Kenya Tourism Board, Brand Kenya and the Export Promotion Council. All can, however, make suggestions to government where they see the scope for improvement to legislation and regulation. Additionally, there are numerous other permanent bodies such as the National Economics \& Social Council, the National Trade Facilitation Committee and the National Consultative Committee of the East Africa Political Federation all of which can have private sector representatives but are more likely to offer a platform for dialogue than an ability to reform regulation. However, the Government regularly creates task forces and technical committees which might consider reforms to regulation or be responsible for the initial implementation of new regulation, but which are time-limited and which are hard to track with no central database.

William Agunda (2018), Kenya's deputy Auditor General, has summarised the legislation in Kenya intended to promote integrity and probity in public office. Whilst the legislation mostly pertains to officials, much of it is also relevant to those holding public appointments. It includes the Republic of Kenya Code of Regulations, 2006, which has a section on the rules of conduct in public service, Public Officer Ethics Act, 2003, the Constitution, which covers integrity, values and principles of public service, and the Leadership and Integrity Act, 2012. Agunda also explains that those who aspire to public office are normally recruited by advertising 
positions and appointment on the basis of qualification and merit (2018: 6). Whilst it is known that business associations in Kenya participate in government committees (Irwin 2021), the degree of involvement has been largely hidden until now.

Appointments to government committees can be controversial due to cronyism or acceding to demands of noisy interest groups (Carson \& Lubensky 2009). Chalmers observes the European Commission's need for knowledge and technical expertise and claims that it casts its net widely specifically to seek a 'diversity of viewpoints' from a broad range of experts [...] including business interests as well as other interests (2014: 977). He further notes, however, that the appointment of nominees is itself subject to considerable lobbying efforts, with interest groups vying to get a seat at the table. This may well be a problem in Kenya. Obang'o (2013), for example, argues that African governments deliberately set up complex and bureaucratic mechanisms to stifle policy reform relying on patronage to fill public offices resulting in appointees who are loyal to the government but also in low levels of integrity and trust. Nevertheless, Kenya has adopted some legislation intended to make the process of appointments more transparent. For example, the Public Appointments (Parliamentary Approval) Act, 2011 sets out procedures to be followed for any public office for which parliamentary approval is required.

\section{Approach to the research}

Identifying parastatal organisations and their board members is a challenge in Kenya given the lack of a national register and no independent monitoring (in the EU the self-appointed Alliance for Lobbying Transparency and Ethics RegulationALTER-EU_-shines a light on the advisory committees). In Kenya, as noted earlier, the High Court identified 128 parastatals (The Citizen 2021). The State Corporations Advisory Committee lists some parastatals on its website (though admits that it was last updated in 2015); an independent website maintained by Victor Matara (victormatara.com) lists many more and claims to have last updated its list in March 2021. However, not all parastatals have websites, not all of those that do have websites list their board members and not all of those that list their board members also

Table 1 Parastatals and government corporations

\begin{tabular}{lr}
\hline State owned enterprise & 72 \\
Higher \& further education & 42 \\
Regulatory & 64 \\
Regional development agency & 7 \\
Research institute & 18 \\
Promotional organisation & 2 \\
Other & 15 \\
Total & 220 \\
\hline
\end{tabular}

Sources: State Corporations Advisory Committee; victormatara. com; authors' research 
describe their affiliations. We used these sources but additionally identified parastatals from personal knowledge, web searches and talking to business membership organisations. We then used a snowball technique whereby whenever a parastatal organisation mentioned another, we checked that one as well. The results are summarised in Table 1.

In total, we identified some 220 government owned entities of which 64 have a primarily regulatory function, that is a function to advise government on regulation or to implement regulation. Whilst other parastatals may well wish to influence policy, they need to lobby like any other interest group. They can be of more interest, however, when they also have a seat on a board or committee with a regulatory function. We were able to identify board membership, through internet searching, for 61 of the 220 and for 42 of the 64 organisations perceived to have a regulatory function.

Separately, we approached business membership organisations and other interest groups that either we knew or believed to have members of staff on government committees and undertook semi-structured interviews with a member of staff, typically the CEO or, if they had one, the director of public affairs. Questions covered which committees gave them an enshrined right to nominate a member (and whether they had lobbied originally for that right); whether the government asks them to put forward nominees for other committees; which other committees had appointed one of their representatives; whether they were proactive in seeking to place nominees on to government committees; and we asked about the challenges in securing appointments. Other than asking for the names of representatives, which should be in the public domain, we did not seek any personal information. In all, we interviewed 19 interest groups of which 16 were BMOs. One of the results of the interviews was that we identified that there are many more government committees beyond the parastatal boards. There are, for example, many task forces set up to review existing regulation or to consider new regulation or to oversee the implementation of recently agreed regulation. There are also many other committees. Given the lack of a register of these advisory committees and the fact that few of them have anything more than a passing reference on a Ministry website, we cannot be sure how many there are. However, the number of people nominated by the Kenya Private Sector Association (the apex (or peak) association) implies that the number is high, probably in the low hundreds.

The research was undertaken whilst movement in Kenya was restricted as a result of COVID-19 and so most interviews were undertaken on zoom or telephone having sent a copy of the questions in advance so that respondents could prepare. Interviews typically lasted about one half hour.

\section{Interest group representation}

We have thus analysed the boards of 61 parastatals based on information that they provide publicly, which accounts for about one quarter of the apparent total but more than half of those with a regulatory function. Some are clear about the way in which people are appointed - indeed, in some cases, the enabling legislation defines 
exactly who should be represented. In some cases, it is clear that people are representing an interest group; in others all that can be said is that they work in the private sector or in a civil society organisation. It is usually clear when people represent a Ministry or a department within a Ministry or another parastatal. We were able to discern the representation for 83 per cent of board members.

For the parastatals concerned with regulation, the analysis suggests that 46 members (that is $12 \%$ of all committee members) are nominees of BMOs with a further 55 (13\% of all members) other private sector representatives. Other interests only have 19 members (5\% of all members) with the Central Organisation of Trades Unions having seven positions (and other trades unions a further one) and the Consumers' Federation of Kenya (a civil society organisation) having four positions.

It appears that BMOs can nominate a relatively high number of people by right, some six are members of the National Construction Authority and a further six are Federation of Kenya Employers' representatives, on boards where the so-called social partners (that is employers, workers and government) are all represented. There are just five other examples of government committees in which BMOs have the right to nominate members, giving a total of 10 committees with automatic BMO representation. BMOs have been successful, however, in securing appointments on a further 12 committees. There are a total of 34 committees $(81 \%)$ that have at least one member drawn from the private sector. Just 14 committees have a member drawn from other interest groups. Seven committees either have no representatives from interest groups or do not state any affiliation. The only parastatal that gives the impression of genuine balance is the National Construction Authority, with a total of 14 directors, of which six come from BMOs apparently by right, one other comes from the private sector, two represent 'other special interests' and the balance come from the public sector. This, however, is unusual—some parastatals have every member coming from the public sector.

The interviews with business associations revealed that out of 19 interest groups, 10 are represented on some 34 regulatory authorities and nine are or have been represented on 36 task forces or technical committees considering regulatory reform, though many of these task forces do not feature on any website and are thus not included in the desk research.

One of the insights from the interviews was that most respondents struggled to name the committees, boards and taskforces on which their BMO is represented let alone the names of their representatives. This perhaps suggests that most associations are not tracking the work of these committees and are thus unlikely to maximise the benefit from representation.

Many committees are represented on other committees, potentially offering an indirect route to influence the outcome of deliberation, though not many individuals are on more than one committee. For example, the Central Bank of Kenya has three representatives on the Capital Markets Authority and one on each of the Export Processing Zones Authority and the Insurance Regulatory Authority. The Capital Markets Authority also has a representative on the Insurance Regulatory Authority. The lack of a register makes it hard for anyone to track these cross-representations. Future research could explore whether these representatives are there because they bring particular expertise or whether their role is one of exercising control. 


\section{Business association representation}

BMO representation is variable. One might expect the apex association, Kenya Private Sector Association (KEPSA) to be the one most represented on committees and boards and, indeed, it is. Some 73 of its members and 11 staff represent the organisation on 73 committees (thus making KEPSA responsible for 50 per cent of interest group representation on government committees). Some committees have multiple representation and some 14 people sit on more than one committee, with the busiest sitting on six committees. Whilst some boards and committees do have membership reserved to specified associations or interest groups, KEPSA explains that they do not have any earmarked representation. They say that the key challenge is not in securing appointments, but rather in ensuring effective participation and achieving the objectives of the committee. They note that often there are irregularities in appointing committee members, that resolution takes a long time, and thus there is a delay to committee decisions. They say that invitations to participate sometimes come at short notice making it difficult to participate. They note that some committee meetings are held outside Nairobi making it difficult for participants to attend due to budgetary constraints. KEPSA is not proactive in nominating people to committees; they say this is because many of the committees are set up by government as part of the "policy making process and KEPSA only gets to know about policy or legislative [proposals] if and when the government invites public participation". KEPSA claims, however, occasionally to initiate policy proposals that are adopted by the government, for example, the National Investment Policy. And KEPSA is now represented on the National Investment Policy Committee. It is also worth noting that KEPSA is not only represented on the National Trade Facilitation Committee but also has recently been appointed as co-chair. Whilst NTFC has no direct control over regulation, it can be a powerful influencer.

The Federation of Kenya Employers, as one of the social partners, participates, as of right, on several government committees related to labour law. This is as close as the Government of Kenya gets to being corporatist. Specifically, FKE is a member of the National Social Security Fund, with two members out of 10, the National Industrial Training Authority, the Higher Education Loans Board, the Commission for University Education, the National Labour Board, the National Hospital Insurance Fund, the Salaries and Remuneration Commission and the National Employment Authority, though it should be noted that not all of these have a regulatory function. It is also invited by government to nominate people to other committees including, currently, the Immigration Committee, the Decent Work Committee and the Unemployment Fund Committee. FKE says that the government "views them as the go-to organisation on matters affecting employers".

The Kenya Association of Manufacturers (KAM), possibly Kenya's most professional BMO, has nominees on the Export Processing Zones Authority, the Kenya Urban Roads Authority, the Kenya National Highways Authority, the Kenya Roads Board, the Kenya Industrial Property Institute and the Scrap Metal 
Council all of which have some regulatory functions. Additionally, it has membership of ad hoc committees - including one currently reviewing Kenya Bureau of Standards (KEBS) standards and one reviewing National Environment Management Authority (NEMA) standards as well as sitting on the County Budgets $\&$ Economic Forum. KAM perceives a degree of competition from other BMOs, especially KEPSA, to secure appointment of its nominees. Not surprisingly, KAM argues that it is better placed to handle sector-specific issues, though most of the committees on which it sits do not have a sector focus. KAM requires all its nominees to undergo vetting and be approved by its governance committee before the names are forwarded to the government institutions. The KAM board is kept informed about all public institution appointments so that policy issues can be identified and channelled accordingly. KAM has worked to place nominees on the boards of both the Kenya Revenue Authority and the Kenya Ports Authority though without success though both agencies do sometimes invite KAM to join specialist sub-committees.

KAM mentioned that there have been instances where the law requires a KAM nominee but the nomination has been made directly by the Ministry: often, then, "the nominee does not serve the interests of the association but [rather] of the nominating authority". Government does, however, often invite nominations, especially to technical committees because, KAM claims, of their approach to addressing policy issues, which is one of proposing credible solutions rather than complaining and criticising the government. They endeavour to understand the intention of the government (which, KAM notes, is "sometimes skewed to the government's interests") and show them the potential impact of such a policy on the private sector. They research the issue and formulate proposals that benefit both the government and the private sector. They encourage dialogue and only go to court as a last resort, when and where dialogue fails. An example is the minimum tax law which they opposed. KAM managed to secure a court order to stop implementation until the matter is heard and determined. They try to ensure that the person handling an issue is the one with the most appropriate expertise: that way they expect to "add value to the process, to their members and to the government".

In most countries, one might expect the national chamber to be well represented but it seems that the Kenya National Chamber of Commerce \& Industry struggles to be heard. Not one committee has a position earmarked for KNCCI. It is a member of the KEBS Standard Regulation Committee and, when the interviews were undertaken, it was only occasionally invited to participate in meetings of the Micro and Small Enterprises Authority (MSEA) Trade Remediation Committee and the Ministry of Trade's African Continently Free Trade Agreement (AfCFTA) Committee. (In November 2021, MSEA appointed a new chair who was nominated by $\mathrm{KNCCI}$ ). KNCCI is not proactive in seeking appointment to government committees. (Tables 2 and 3) It does say that chamber members sometimes seek appointment on a personal basis and complains that they then represent themselves rather than the chamber. It also complains that it has no budget to attend meetings if they are held outside of Nairobi.

The Shippers' Council of East Africa (SCEA) is not on any committee as of right, but following invitations for nominations from government, SCEA secured 
Table 2 Representation on 36 parastatals and government corporations with regulatory functions

\begin{tabular}{llll}
\hline & Committees & Members & $\begin{array}{c}\text { Proportion } \\
\text { of all mem- } \\
\text { bers }\end{array}$ \\
\hline BMO nominees by right & 10 & 23 & $6 \%$ \\
BMO nominees through competitive selection & 12 & 23 & $6 \%$ \\
Other private sector nominees & 23 & 55 & $13 \%$ \\
Other interest group nominees & 14 & 19 & $5 \%$ \\
Committees with no known private sector or inter- & 7 & & \\
$\quad$ est group representation & 42 & 415 & \\
Total directors & & & \\
\hline
\end{tabular}

appointments to the National Development Implementation Technical Committee (one of four committees set up by President Kenyatta to oversee the so-called Big Four strategic objectives enshrined in Vision 2030), the Port Advisory Committee, the National Trade Facilitation Committee and now chairs one of four thematic working groups), the Port Charter, the Northern Corridor Transit \& Transport Coordination Authority and the Public Private Partnership Committee. It is also on the board of KenTrade. SCEA explains that "in some cases where appointment is done by the Executive (ministers), there tend to be political interests and appointments are made to serve those interests".

The Kenya Association of Tour Operators is represented on the Kenya Roads Board and the Tourism Regulatory Authority - both of which are required to have a representative from the tourism sector but not necessarily KATO - and the Kenya Tourism Board - which has a slot reserved for KATO's chairman. It is represented on other committees such as the Kenya Wildlife Service and the tourism standards committee of the Kenya Bureau of Standards.

Other BMOs with earmarked representation include the Architects' Association of Kenya with membership of the National Construction Authority Board and the Public Procurement Regulatory Authority - they claim that membership was mandated in the legislation as a result of their lobbying when the bill was debated - the Seed Trades Association of Kenya with membership of the Seeds \& Plants (variety and release) Regulations 2016 committee, the consortium for development of the soya bean five year strategy and the National Variety Release Committee and the Kenya Motor Repairers' Association which sits on the Kenya Bureau of Standards Technical Committee.

BMOs actively participating in task forces considering or reviewing regulation include the Kenya Property Developers' Association, two members appointed to the task force to develop regulations to implement the Sectional Properties Act 2020 and two members on the task force to formulate construction industry policy; the Association of Kenya Suppliers which is a member of a government task force developing regulations to cover the retail sector and expects its CEO to be included on a retail sector dispute resolution committee that has been proposed by the government. 


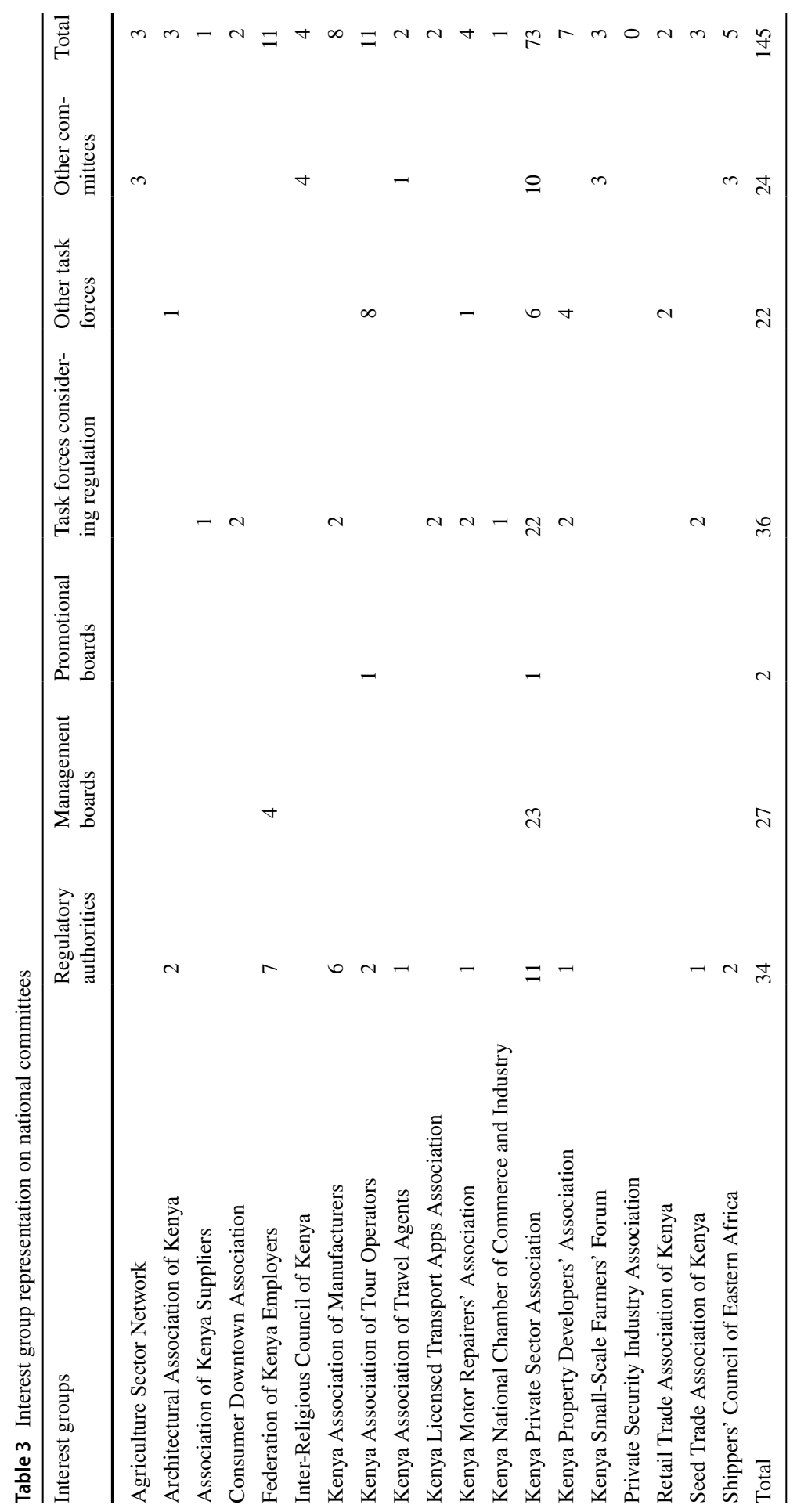


The Private Security Industry Association is supposed to be a member of the Private Security Regulatory Authority, created by the legislation, but the government encouraged the formation of a new association and then appointed one of them as the representative of the security sector on the committee.

\section{Other interest group representation}

The Inter-Religious Council of Kenya (IRCK) is a multi-faith civil society organisation. It is not represented on any of the parastatal boards, but does sit on several other committees including the Constituencies Development Fund Committees, the Independent Electoral and Boundaries Commission Nomination Committee (which came about as a result of their mediation between the Jubilee Coalition and the National Super Alliance after the 2017 elections) and the National Social Budgetary Observatory Committee. They are sometimes invited by government to propose nominees and were successful with a sub-group of the National Emergency Response Committee on Coronavirus and the Ministry of Health's HIV and AIDS Management Committee.

The Kenya Small Scale Farmers' Forum (KESSFF), representing farmers and seeing itself as a civil society organisation rather than a business association, suggests that civil society organisations are not empowered enough to benefit from ear-marked positions on committees (though the Consumers' Federation of Kenya has such privileges). However, they also note a "lack of trust by government in non-governmental organisations and civil society organisations due to their lack of integrity [...] including misappropriation of funds" intended for small scale farmers. KESSFF has, however, adopted a range of advocacy techniques including going to court. In partnership with Econews Africa, for example, they currently have a lawsuit in the High Court delaying ratification of the Kenya-UK Economic Partnership Agreement where they seek to ensure transparency and effective participation. They report, too, a meeting with the president in 2020 to discuss the plight of the tea farmers which resulted in several reforms and with the management of the tea factories taken away from Kenya Tea Development Authority and given to the farmers.

The Consumer Downtown Association (CDA), a smaller rival to the Consumers' Federation of Kenya (COFEK) notes that COFEK is able to nominate a member of the Communications Authority of Kenya Board. CDA has contested this in court arguing that this is discriminatory as COFEK is just one of the many associations representing consumers. There is discontent amongst the others that COFEK presents itself as the umbrella when it is not. However, CDA has been invited to nominate members of the Kenya Bureau of Standards Food Safety Standards Development Sub-Committee and Transport Sub-Committee. They have sought appointment to the Kenya Consumer Protection Advisory Committee, which is able to appoint up to four consumer organisation representatives, but only COFEK has been appointed. 


\section{Discussion}

Business associations, between them, have what appears to be a good level representation on government committees and especially on those concerned with policy and regulation. This reflects the assertions of Fraussen et al. (2015) not only that organisations with a clear interest in improving the business environment might seek representation on committees dealing with aspects of this topic but also that their members will benefit directly from such improvement. There is little comparative data. Binderkrantz and Christiansen (2015) claimed Denmark, in 2010, and reflecting Denmark's more corporatist approach, had 273 government committees all with interest group representation but, as noted earlier, with only three looking at policy reform. In Kenya, the majority of the committees for which we have data have business association representation. This finding is positive: indeed, Lijhart describes a consensus model of democracy as one of "broad participation in government and broad agreement on the policies (2012: 2) and suggests that this participation is characterised by "inclusiveness, bargaining and compromise". Securing membership of government committees is rather more exclusive than other advocacy strategies since it relies on appointment by government (Rasmussen \& Gross 2015) but does offer potential to influence.

There are some instances of legislation requiring business association and other interest group participation. However, private sector, and specifically business association, appointments are not universal and the means of appointment is generally opaque rather than transparent. In most cases, BMOs have to be proactive to secure positions for their nominees. Other interest groups are barely represented at all. All the representation is of sectional groups; we found no instances of representation by cause groups. And the high level of cross-representation from other parastatals and committees makes it relatively easy for the government to exercise control, if it so desires.

There is much debate in the interest group literature about whether the incorporation of interest groups into government committees makes them more corporatist. Whether the Government of Kenya is at the corporatist end of spectrum or at the pluralist end is not a focus of this research, though the degree of involvement by, and the number of, interest groups, and the competition for representation would seem to place Kenya towards the pluralist end of the spectrum.

As observed by Fraussen et al. (2015), representatives of businesses associations in particular and civil society more generally potentially have much to offer boards and committees by way of knowledge and expertise. We do not argue that any groups should be prioritised over others to represent the private sector or civil society but we do argue, reflecting Agunda (2018), that there should be a better balance and we further argue that positions should be advertised and people appointed on merit. We also argue that the length of term, and whether there is scope for re-appointment, should be public. It is clear that there is a degree of competition amongst business associations to secure appointment. Whilst this may ensure that the most appropriate person is appointed it should not prevent close cooperation between BMOs to ensure that representatives are fully briefed 
on the topics to be discussed. However, there is no evidence to suggest there is any cooperation. It is not clear to what extent committees seek to avoid conflicts of interest, but we have not found any evidence that they aim to prevent conflicts.

KAM clearly takes very seriously the business of securing membership of government committees. However, it seems that many associations, having worked hard to nominate representatives to committees, then forget about them and, as a result, potentially fail to use their membership to advantage. Associations should aim to take representation on committees as seriously as KAM does. They should use their committee memberships as a way of putting important issues on to the public policy agenda, as a way of securing advance intelligence about forthcoming regulation and regulatory reform so that they can prepare and as a way of influencing policy outcomes. Ideally, there would be a code of ethics for interest group representatives but, in the absence of a code, it would be sensible for the interest groups themselves to agree and implement a voluntary code. We would go further and recommend the creation of a register which should cover all government owned entities and be publicly available.

This research has identified many parastatal organisations and revealed that there are many additional task forces and committees which have a role in reviewing or proposing or implementing regulation though there is no public register. It has uncovered the extent to which interest groups and, in particular, business associations are represented on government boards, committees, task forces and technical committees. It appears that there is a very good level of private sector representation and there appears to be a high level of business association representation though it is not always clear whether people have been appointed as individuals or as representatives of associations. It suggests that, overall, there is a low level of transparency.

Being appointed to a government committee essentially makes an interest group an ultimate insider and, even if not able fully to co-create regulation, it enables the gathering of advance intelligence about potential regulatory reforms. However, it seems that only one association has thought through what it needs to do to maximise the benefit from participation in government committees and, though there is a need for further research, it appears business associations and other interest groups could utilise their membership more effectively and could seek to cooperate rather than apparently to compete.

\section{Declarations}

Conflict of interest On behalf of all authors, the corresponding author states that there is no conflict of interest.

\section{References}

Agunda, W.O. 2018. Expectations of integrity in the public office in Kenya, In: London conference: The construction of public office and the pursuit of integrity, London, $4 \mathrm{Jul}$. 
BAF. 2020. Supporting dialogue and advocacy in Kenya: fifteen years of lessons, Nairobi: Business Advocacy Fund

Binderkrantz, A.S., and P.M. Christiansen. 2015. From classic to modern corporatism. interest group representation in Danish public committees in 1975 and 2010. Journal of European Public Policy 22: 1022-1039.

Brown, M.B. 2008. The politics of representation on government advisory committees. Political Research Quarterly 61 (4): 547-560.

Carson, L., and R. Lubensky. 2009. Appointments to boards and committees via lottery, a pathway to fairness and diversity. Journal of Public Affairs 9: 87-94.

Chalmers, A.W. 2014. Getting a seat at the table: capital, capture and expert groups in the European Union. West European Politics 37 (5): 976-992.

Chazan, N., P. Lewis, R. Mortimer, et al. 1999. Politics and society in contemporary Africa, 3rd. London: Palgrave Macmillan.

Christiansen, P.M., A.S. Nørgaard, H. Rommetvedt, et al. 2010. Varieties of democracy: interest groups and corporatist committees in Scandinavian policy making. Voluntas 21: 22-40.

Council of Europe (undated) Civil participation in the decision-making process: the code of good practice, Strasbourg: Council of Europe

de Stefano, V. 2021. Not as simple as it seems the ILO and the personal scope of the international labour standards. International Labour Review. 160 (3): 387-406.

Dür, A., and G. Mateo. 2012. Who lobbies the European union? national interest groups in a multilevel polity. Journal of European Public Policy 19 (7): 969-987.

Fink-Hafner, D., and A. Krašovec. 2005. Is consultation everything? the influence of interest groups on parliamentary working bodies in Slovenia. Czech Sociological Review 41 (3): 401-421.

Fraussen, B., J. Beyers, and T. Donas. 2015. The expanding core and varying degrees of insiderness: institutionalised interest group access to advisory councils. Political Studies 63 (3): 569-588.

Irwin, D. 2021. African approaches to dialogue and advocacy. In The Palgrave Encyclopedia of Interest Groups, Lobbying and Public Affairs, ed. P. Harris, A. Bitonti, C.S. Fleisher, and A. Skorkjaer Bindekrantz. Basingstoke Palgrave Macmillan.

Irwin, D., and M. Githinji. 2016. Business associations in Kenya: the success factors. Journal of Public Affairs 16 (2): 162-180.

Jordan, A.G., and W.A. Maloney. 2007. Democracy and interest groups: enhancing participation. Basingstoke: Palgrave Macmillan.

Kimenyi, M.S., and A. Datta. 2011. Think tanks in sub Saharan Africa: how the political landscape has influenced their origins. London: ODI.

Kuada, J. 2015. Private enterprise led economic development in sub-Saharan Africa. Basingstoke, UK: Palgrave Macmillan.

Lijhart, A. 2012. Patterns of Democracy: government forms and performance in thirty six countries 2 nd edition. New Haven: Yale University Press.

Mahoney, C. 2008. Brussels versus the beltway: advocacy in the United States and the European Union. Washington: Georgetown University Press.

Maloney, W.A., G. Jordan, and A.M. Mclaughlin. 1994. Interest groups and public policy: the insider/ outsider model revisited. Journal of Public Policy 9: 17-38.

McGrath, C. 2013. They are not my people: Barack Obama on lobbying and lobbyists. Journal of Public Affairs 13 (3): 308-328.

Metz, J. 2014. EU Commission expert groups: between inclusive and effective policy-making. In Expertise and Democacy, ed. Catherine Holst. Oslo: Centre for European Studies, University of Oslo.

Mintrom, M. 2012. Contemporary policy analysis. New York: Oxford University Press.

Obang'o, S.O. 2013. Particularistic exchanges and pacts of domination in Africa: examining how patronage appointments may have increased resistance to public sector reforms in Kenya. International Public Management Review 14 (1): 27-46.

OECD. 2021. Lobbying in the 21st century: transparency, integrity and access. Paris: OECD Publishing.

Rasmussen, A., and V. Gross. 2015. Biased access? Exploring selection to advisory committees. European Political Science Review 7 (3): 343-372.

TI. 2015. International standards for lobbying regulation: towards greater transparency, integrity and participation. Berlin: Transparency International.

Walter, D. 2021. Court declares President Kenyatta's parastatal appointments unconstitutional, The Citizen, 21 May [Online] available at: iga.fyi/cit2105. Accessed: 27 May 2021. 
Watta, D. 2021. Why it is critical to regulate how board directors are picked, work, [Online] available at: iga.fyi/bd2106, Accessed: 21 Jun 2021.

Wiredu, K. 2015. Democracy and consensus in African traditional politics, [Online] available at: https:// them.polylog.org/2/fwk-en.htm, Accessed: 10 June 2015

World Bank. 2005. Building the capacity of business membership organisations 2nd Edn. Washington: World Bank \& IFC.

Publisher's Note Springer Nature remains neutral with regard to jurisdictional claims in published maps and institutional affiliations. 